\title{
The Impact of Financial Performance, Financial Risk, Liquidity, and Corporate Governance on Corporate Value
}

\author{
YunitaKarlina \\ Soegijapranata Catholic University \\ yunitakarlina@gmail.com \\ Andreas Lako \\ Soegijapranata Catholic University \\ a_lako@yahoo.com
}

\begin{abstract}
The purpose of this study is to analyze the impact of financial performance, financial risk, liquidity, and corporate governance $(\mathrm{CG})$ on the corporate value in the period $t_{0}$ and $t_{+1}$. The proxy for financial performance, financial risk, liquidity, and corporate governance is respectively return on equity (ROE), debt to assets ratio (DAR), current ratio (CR), and corporate governance perception index (CGPI). The proxy for corporate value is price to book value (PBV). The method for analysis data is multiple linear regression analysis. The results show that financial performance has positive impact on the corporate value in the period $t_{0}$ and $t_{+1}$ on one percent level of significance. However, financial risk and liquidity have positive impact on the corporate value in the period $t_{0}$ and $t_{+1}$ but the impact is not statistically significant. CG shows different impact on the corporate value in the period $t_{0}$ and $t_{+1}$ in which it indicates negative impact in the period $t_{0}$ but positive impact in the periode $t_{+1}$. The impacts are however statistically insignificant. Generally, the results indicate that financial performance is the main factor that increases corporate value.
\end{abstract}

Keywords: corporate governance, corporate value, financial performance, financial risk, liquidity

\section{INTRODUCTION}

Corporate value indicates conditions of a company, which cover evaluation on its current performance and its prospect in the future (Brealey, Myers, \& Marcus, 2012a). Evaluation of investors toward company's conditions is reflected on price to book value (PBV). PBV shows ratio between stock market price and book value of each share. It can also be called as market value to book value ratio (Brigham \& Houston, 2014a). 
There are factors influencing stock price and book value of a company. Stock price is influenced by external and internal factors. External factors are factors beyond the control of a company such as political, economic, and social conditions of a country; menwhile internal factors relate to managerial goals in terms of decisions to make price of the stocks maximum and thus it maximizes the wealth of shareholders. Final results of all financial and operational decisions of the company are reflected in profitability ratios (Brigham \& Houston, 2014a). One of the profitability ratio commonly used in research is return on equity (ROE). ROE is to measure management capability to generate profit aiming at leveraging the owner's equity. The studies of Marlina (2013) and Marangu \& Jagongo (2014) show that higher ROE means higher capability to leverage value of the company.

On the other side, book value or fundamental value is the net amount of assets after it is deducted by allliabilities. Thus, book value is influenced by amount of assets and liabilities of the company. Company's assets are funded by capitals gathered from either independent entities (debts) or the owners (equity). Brealey, Myers, \& Marcus (2012b) stated that debts increase financial risks. The extent to which debts are used in the company's capital structure can be measured using debts to assets ratio (DAR). The study of Safitri, Handayani, \& Nuzula (2014) showed that capital structure had negative impacts on the corporate value. In the case a company has debts, it has obligation to pay off the debts. Ability of the company to pay all their short-term debts using their current assets can measured by current ratio (CR) (Brigham \& Houston, 2014a). CR is a liquidity ratio. The research of Nurhayati (2013) and Stiyarini \& Santoso (2016) resulted in liquidity had positive influence but insignificant statistically to the corporate value. However the research of Purwanto\& Agustin (2017) indicated that CR had negatif influence to corporate value. 
Management efforts to increase their corporate value receive the government supports. Since the crisis in Asia in 1998, Indonesian government realises the importance of strengthening framework of corporate governance (CG). CG is a system that can be used to manage and control the company in providing value added for all the stakeholders (Sutedi, 2011). According to Sadeli (2011), company investment in good corporate governance (GCG) will increase corporate value, which in turn gives direct benefits to the stockholders.

One effort to support implementation of CG in Indonesia is to give incentives or appreciations to every company that implements principles of CG. IICG Award-Most Trusted Award is an award given to companies based on corporate governance perception index (CGPI) and the award has been granted since 2001 (OJK, 2014). The research by Inastri \& Mimba (2017) and Sulastri \& Nurdiansyah (2017) showed that higher score of CGPI is able to increase corporate value.

Corporate value changes according to conditions and new information the investors have about the prospect of the company (Brigham \& Houston, 2014a). Information needed by investors and analysts to understand the financial performance, financial risks, liquidity of a company are mostly available in the company's financial reports. Annual financial report of a company is published at the beginning of the following year, while CGPI score is published in SWA magazine at the end-of-the-year edition (end of December-beginning of January). Therefore, the impact of the publication to the investors' decisions can have effects only in the following year $\left(\mathrm{t}_{+1}\right)$.

This research is to analyize the impact of financial performance (return on equity $\mathrm{ROE}$ ), financial risks (debt to assets ratio - DAR), liquidity (current ratio - CR), and corporate governance (corporate governance perception index - CGPI) on corporate value (price to book value $-\mathrm{PBV})$ in the current year $\left(\mathrm{t}_{0}\right)$ and the following year $\left(\mathrm{t}_{+1}\right)$. Conceptually, the research 
has benefits in explaining relationship between financial performance, financial risks, liqudity, $\mathrm{CG}$ and corporate value. Practical benefit of the research is to give reference for the corporate management in making decisions to increase corporate value.

\section{LITERATURE REVIEW}

\section{Corporate Value}

Brealey et al. (2012a) state that corporate value depicts conditions of a company in terms of current performance and its prospect in the future. Price to book value (PBV) ratio or ratio of market value/book value reflects investors' evaluation on company's conditions (Brigham \& Houston, 2014a). According to Damodaran (2012), PBV is calculated from return on equity (ROE), payout ratio, risk level (through discount rate), and profit growth. The advantage of PBV is that book value is a relatively stabil value compared to market price and by using a consistent accounting standard, we can compare PBV of similar companies and also can apply PBV to evaluate companies with negative profit.

\section{Financial Performance and Corporate Value}

Financial performance depicts company's performance achieved by a company in a particular periode. Brigham and Houston (2014a) stated that the final results of financial and operational decisions in a company can be measured using profitability ratios. A profitability ratio used to measure ability of the management to generate profit aimed to increasethe owner's equity is return on equity (ROE). Things indicate conditions of a company affect decisions of the investors (Fahmi, 2015). When investors value performance of the company as good, then such valuation will bring the stock price of the company up. As a result, corporate value will also increase. 
The research of Safitri, Handayani, \& Nuzula (2014) concluded that profitability (NPM, ROA, ROE, EPS) had positive impact on corporate value (PBV and stock price) using one percent level of significance. Marlina (2013) and Marangu \& Jagongo (2014) stated that ROE had positive impact on PBV with one percent level of significance. Similarly, Hariyanto \& Lestari (2015) also indicated that ROE had positive but not significant influence to PBV. Based on the discussion, the hypothesis developed for this research is:

$\mathrm{H}_{1}=$ Financial performance $(\mathrm{ROE})$ has positive influence on corporate value $(\mathrm{PBV})$ in $\mathrm{t}_{0}$ and $t_{+1}$.

\section{Financial Risk and Corporate Value}

According to Brigham \& Houston (2014b), financial risk is additional risks for common stockholders due to decision of the corporate to get funding from debts. Proportion of debts in capital structure of the company can be measured using debt to assets ratio (DAR). The research of Safitri et al. (2014) showed that capital structure (DAR, DER) had negative impact on corporate value (PBV and stock price) under five percent level of significance. However, the research by Dwipayana \& Suaryana (2016) resulted in positive impact of DAR on corporate value under one percent level of significance. Pratiwi and Rahayu (2015) also showed similar result with ten percent level of significance.

The researches show different results on the influence of DAR on corporate value (PBV). The concepts on DAR state that DAR measures usage level of debts in the company's capital structure (Brigham \& Houston, 2014a). As stated by Brealey, Myers, \& Marcus (2012b), debts increase financial risk. When high value of DAR is considered as negative news for investorssince it also indicates higher risk that the company must deal with, it thus can lower price of the company's stocks. This will in turn decrease corporate value. Based on this, the hypothesis developed for the research is: 
$\mathrm{H}_{2}=$ Financial risk (DAR) has negative influence on corporate value (PBV) in $t_{0}$ and $t_{+1}$.

\section{Liquidity and Corporate Value}

Liquidity indicates capability of a company to pay their short-term debts. One of the liquidity ratios is current ratio (CR). Nurhayati (2013) and Stiyarini \& Santoso (2016) in their studies showed that liquidity (CR) influenced positively to corporate value (PBV) but its influence is not significant. On the opposite, the result of Purwanto \& Agustin (2017) showed negative influence of $\mathrm{CR}$ to corporate value (PBV) with the level of significance of one percent.

The concepts of liquidity state that CR indicates capability of a company to pay their short-term liabilities using current assets (Brigham \& Houston, 2014a). A company that is very liquid indicates the company has a healty financial condition. When high CR is seen as positive signal by investors, $\mathrm{CR}$ is thus able to leverage price of company's stocks. Based on the discussion above, the hypothesis develeoped in this research is:

$\mathrm{H}_{3}=$ Liquitdity $(\mathrm{CR})$ influences positively corporate value (PBV) in $\mathrm{t}_{0}$ dan $\mathrm{t}_{+1}$.

\section{Corporate Governance and Corporate Value}

Corporate governance (CG) is a system enabling to manage and control organization in providing value added for all stakeholders (Sutedi, 2011). Implementation of CG concept is based on the principles of transparency, accountability, responsibility, independency, and fairness (Komite Nasional Kebijakan Governance, 2006). How well the implementation of CG can be seen from the value of corporate governance perception index (CGPI). An organization with total score of 85.00-100.00 is labelled as Most Trusted Company, while those with total score of 70.00-84.99 are considered as Trusted Company, and those having 55.00-69.99 total score are awarded as Fairly Trusted Company (SWA, 2016). 
In the last few years, Indonesian companies start to realize the importance of CG implementation as one aspect of business strategy. Organizations that have been in several evaluations of IICG in relation to their implementation of CG keep trying to improve their performance. This is refelected by the CGPI score that has generally positive trend each year (SWA, 2016). New comers also show their seriousness in developing good corporate governance.

The result of Inastri \& Mimba (2017) showed that CG (CGPI) had positive impact on corportae value (PBV) with five percent level of significance. Pratiwi \& Rahayu (2015) indicated that CG (CGPI) influenced positively to corportae value (PBV) but statistically insignificant. The research of Sulastri \& Nurdiansyah (2017) showed that CG (CGPI) influenced positively to corporate value with one percent of significance level. Based on the discussion, the hypothesis for the research is developed as follows:

$\mathrm{H}_{4}=$ Corporate Governance (CGPI) influences positively the corporate value (PBV) in $\mathrm{t}_{0}$ dan $\mathrm{t}_{+1}$.

\section{METHODS}

\section{Population and Samples}

Population in this research is all companies involved in ranking and awarding activities conducted by IICG and SWA magazine based on the evaluation of CGPI. Sample of the research is determined using purposive sampling method. The criteria for selecting the companies are that they are in the CGPI program in 2010-2015, are registered in the Indonesia Stock Exchange (IDX), are operating in the finance industry, have stocks actively traded in the period of $t_{0}$ dan $t_{+1}$, and no outlier data. Based on these criteria, there are 54 companies fit for samples. 


\section{Operational Definition of Research Variables}

\section{Return on equity (ROE)}

$\mathrm{ROE}=$ Net income/Total equity . .1

\section{Debt to assets ratio (DAR)}

DAR $=$ Total debt $/$ Total assets 2

\section{Current ratio (CR)}

$\mathrm{CR}=$ Current assets/Current liabilities 3

\section{Corporate governance perception index (CGPI)}

CGPI is total scores of the four ratios: self assessment, documents, papers, and observations. Maximum score for CGPI is 100.

\section{Price to book value (PBV)}

$\mathrm{PBV}=$ Close price/Book value per share 4

\section{Models for Hypothesis Test}

Analysis data method in this research is multiple linier regression. Since the reseacrch is conducted for the period $t_{0}$ and $t_{+1}$, thus there will be two regression models. The first model is to test the impact of financial performance (ROE), financial risk (DAR), liquidity (CR), and $\mathrm{CG}(\mathrm{CGPI})$ on corporate value (PBV) in the period $\mathrm{t}_{0}\left(\mathrm{H}_{1}, \mathrm{H}_{2}, \mathrm{H}_{3}, \mathrm{H}_{4}\right)$ as follows:

Model (1)

$\mathrm{PBV}_{\mathrm{t} 0}=\exists_{0}+\exists_{1} \mathrm{ROE}+\exists_{2} \mathrm{DAR}+\exists_{3} \mathrm{CR}+\exists_{4} \mathrm{CGPI}+e$ 5

The second regression model is to test the impact of financial performance (ROE), financial risk (DAR), liquidity (CR), and CG (CGPI) on corporate value (PBV) in the period $\mathrm{t}_{+1}\left(\mathrm{H}_{1}, \mathrm{H}_{2}, \mathrm{H}_{3}, \mathrm{H}_{4}\right)$ as follows: 
Model (2)

$\mathrm{PBV}_{\mathrm{t}+1}=\forall_{0}+\forall_{1} \mathrm{ROE}+\forall_{2} \mathrm{DAR}+\forall_{3} \mathrm{CR}+\forall_{4} \mathrm{CGPI}+e$ .6

In which $\mathrm{PBV}_{\mathrm{t} 0}$ is price to book value in the period $t_{0} ; \mathrm{PBV}_{\mathrm{t}+1}$ is price to book value in the period $\mathrm{t}_{+1} ; \exists$ and $\forall$ are coefficients; ROE is return on equity; DAR is debt to assets ratio; CR is current ratio; CGPI is corporate governance perception index; $e$ is error term or residual.

Criteria for testing the hypothesis are: 1) $\mathrm{H}_{1}$ is accepted if $\exists_{1}$ and $\forall_{1}>0$, while if $\exists_{1}$ and (or) $\forall_{1}<0$ then $\mathrm{H}_{1}$ is rejected; 2) $\mathrm{H}_{2}$ is accepted if $\exists_{2}$ and $\forall_{2}<0$, while if $\exists_{2}$ and (or) $\forall_{2}>0$ then $\mathrm{H}_{2}$ is rejected; 3) $\mathrm{H}_{3}$ is accepted if $\exists_{3}$ and $\forall_{3}>0$, while if $\exists_{3}$ and (or) $\forall_{3}<0$ then $\mathrm{H}_{3}$ is rejected; and 4) $\mathrm{H}_{4}$ is accepted if $\exists_{4}$ and $\forall_{4}>0$, while if $\exists_{4}$ and (or) $\forall_{4}<0$ then $\mathrm{H}_{4}$ is rejected. Criteria for testing whether there is difference between the impact of financial performance, financial risk, liquidity, and CG on corporate value in $t_{0}$ and $t_{+1}$ are:

1. There is difference $(\Delta)$ in coefficient of ROE, DAR, CR, CGPI in the model (2) and the $\operatorname{model}(1)\left(\forall_{1}-\exists_{1}, \forall_{2}-\exists_{2}, \forall_{3}-\exists_{3}, \forall_{4}-\exists_{4}\right)$.

2. There is an increase in adjusted $\mathrm{R}$ square $\left(\bar{R}_{2}^{2}>\bar{R}_{1}^{2}\right)$.

3. Significance of the increase of $\bar{R}^{2}$ is analyzed by comparing $\mathrm{Z}$ value (F-test) and F-table. If $\mathrm{Z}$ value (F-test) > F-table, there is thus significant difference between the impact of financial performance, financial risk, liquidity, and GC on the corporate value in $\mathrm{t}_{0}$ and $\mathrm{t}_{+1}$. Value of $\mathrm{Z}$ is calculated using Z-test Cramer (Lako, 2007):

$Z=\frac{\bar{R}^{2}{ }_{2}-\bar{R}^{2}{ }_{1}}{\sqrt{\sigma^{2}\left(\bar{R}^{2}{ }_{2}\right)+\sigma^{2}\left(\bar{R}^{2}{ }_{1}\right)}} ; \sigma^{2}=\frac{\sum \mu_{i}{ }^{2}}{n-k}$

In which $\bar{R}_{2}^{2}$ is adjusted $\mathrm{R}$ square of the regression Model (2); $\bar{R}^{2}{ }_{1}$ is adjusted R square of the regression Model (1); $\sigma^{2}$ is varians of each $\bar{R}^{2} ; \mu$ is error term; $n$ is number of observation; $k$ is number of parameters including the constant.

\section{Classical Asumption Tests}

Before conducting statistical tests, screening to the data is conducted using classical assumption tests. 


\section{Normality test}

Kolmogorov-Smirnov is to test normality using criteria (Ghozali, 2013): 1) If probability of significance value $<\forall$, then $\mathrm{H}_{0}$ stating that the data are normally distributed is rejected, or the data are not distributed normally; 2) if probability of significance value $>\forall$, then $\mathrm{H}_{0}$ stating that the data are normally distributed is accepted.

\section{Multicolinearity test}

Multicolinearity test is conducted using tolerance and variance inflation factor (VIF), with the criteria for testing are (Ghozali, 2013): 1) If the value of tolerance $\leq 0.10$ and value of $\mathrm{VIF} \geq 10$, then $\mathrm{H}_{0}$ stating that no multicollinearity is rejected, or there is multicollinearity; 2) if value of tolerance $>0.10$ and value of VIF $<10$, then $\mathrm{H}_{0}$ stating that there is no multicollinearity is accepted.

\section{Autocorrelation test}

Autocorrelation test is conducted using Durbin-Watson test (DW test), using criteria as follows (Ghozali, 2013): 1) If $0<\mathrm{DW}<\mathrm{d}_{\mathrm{L}}$, then $\mathrm{H}_{0}$ stating that no positive autocorelation is rejected, or there is positive autocorrelation; 2) if $\mathrm{d}_{\mathrm{L}} \leq \mathrm{DW} \leq \mathrm{d}_{\mathrm{U}}$, then the result is inconclusive; 3) if $d_{U}<D W<\left(4-d_{U}\right)$, then $H_{0}$ stating that no positive or negative autocorrelation is accepted; 4) if $\left(4-d_{U}\right) \leq D W \leq\left(4-d_{L}\right)$, then the result is inconclusive; 5) if $\left(4-d_{L}\right)<D W<4$, then $\mathrm{H}_{0}$ stating that no negative autocorelation is rejected or there is negative autocorelation.

\section{Heteroscedasticity test}

Heteroscedasticity test is conducted using Glejser test with the criteria as follows (Ghozali, 2013): 1) if significance probability $<\forall$, then $\mathrm{H}_{0}$ stating that no heteroscedasticity is rejected, or there is heteroscedasticity; 2) if probability of significance $>\forall$, then $\mathrm{H}_{0}$ stating that there is no heteroscedasticity is accepted. 


\section{RESULTS AND DISCUSSION}

\section{Results}

\section{Descriptive statistics}

Descriptive statistic provides general picture of the research data covering number of observation, minimum, maximum, mean, and standard deviation values. Table 1 presents the description of the research data.

Table 1. Descriptive Statistic

\begin{tabular}{lccccc}
\hline & $\mathrm{N}$ & Minimum & Maximum & Mean & Standard Deviation \\
\hline ROE & 54 & -0.7146 & 0.4310 & 0.136381 & 0.1544891 \\
DAR & 54 & 0.2218 & 0.8403 & 0.498382 & 0.1643801 \\
CR & 54 & 0.4040 & 4.0291 & 1.592770 & 0.8128600 \\
CGPI & 54 & 0.6755 & 0.9118 & 0.815165 & 0.0627480 \\
PBV $_{\text {t }}$ & 54 & 0.4120 & 8.8456 & 2.457424 & 1.5007809 \\
PBV $_{t+1}$ & 54 & 0.2565 & 4.4560 & 2.021243 & 1.1040005 \\
\hline
\end{tabular}

Source: processed secondary data, 2019

Value of $\mathrm{N}$ indicates number of observation which is 54 . ROE represents ratio between net profit and total equity. The distribution pattern of ROE data quite varies. Mean of ROE is 0.136381 indicating that the companies on average are able to produce net profit of 13.64 percent of the total equity. DAR is the ratio of total debts and total assets. The distribution pattern of DAR data in the observation does not vary. On average, 49.84 percent of the companys' assets are funded from debts. The average is however still categorized as medium.

$\mathrm{CR}$ represents ratio of current assets to current liabilities. The $\mathrm{CR}$ data are distributed in less variety of pattern. The mean of CR is higher than one. Thus indicates that the companies are able to pay their short-term liabilities using the current assets. The mean of current assets of the sample companies is 1.59 bigger than their current debts. CGPI indicates the implementation level of CG. The distribution pattern of CGPI data does not vary and thus 
implementation level of CG on the sample companies are similar. The mean of CGPI that is 81.52 indicates that the companies are in the category of trusted company.

$\mathrm{PBV}_{\mathrm{t} 0}$ represents ratio between market value and book value in the period $\mathrm{t}_{0}$. The distribution pattern of $\mathrm{PBV}_{\mathrm{t} 0}$ data is quite varied. The mean of $\mathrm{PBV}_{\mathrm{t} 0}$ that is 2.46 indicates that market value of the companies in the observed periode is 2.46 times of their book value. $\mathrm{PBVt}_{+1}$ indicates ratio of market value and book value in the period $t_{+1}$. The distribution pattern of $\mathrm{PBVt}_{+1}$ data in the observed period is quite varied. The mean of $\mathrm{PBVt}_{+1}$ that is 2.02 reflects the condition in which market value of the companies is on average 2.02 times bigger than their book value.

\section{Normality test}

The hypothesis to detect normality of the data using Kolmogorov-Smirnov is $\mathrm{H}_{0}=$ Data is distributed normally; $\mathrm{H}_{\mathrm{a}}=$ Data is not distributed normally.

Table 2. Normality Test

\begin{tabular}{lcccccc}
\hline & ROE & DAR & CR & CGPI & PBV $_{\mathrm{t} 0}$ & PBV $_{\mathrm{t}+1}$ \\
\hline $\begin{array}{l}\text { Asymp. Sig. } \\
\text { (2-tailed) }\end{array}$ & 0.107 & 0.275 & 0.357 & 0.433 & 0.765 & 0.412 \\
\hline
\end{tabular}

Based on the test results presented in the Table 2, the probability of significance of ROE (0.107), DAR (0.275), CR (0.357), CGPI (0.433), $\mathrm{PBV}_{\mathrm{t} 0}(0.765), \mathrm{PBVt}_{+1}(0.412)>\forall(0.05)$, thus $\mathrm{H}_{0}$ stating that the data is distributed normally is accepted.

\section{Multicolinearity test}

The hypothesis of multicolinearity test using tolerance and VIF is $\mathrm{H}_{0}=$ there is no multicolinearity; $\mathrm{H}_{\mathrm{a}}=$ there is multicolinearity. 
Table 3. Multicolinearity Test

\begin{tabular}{lcc}
\hline & Tolerance & VIF \\
\hline ROE & 0.854 & 1.171 \\
DAR & 0.414 & 2.416 \\
CR & 0.476 & 2.101 \\
CGPI & 0.793 & 1.261 \\
\hline
\end{tabular}

Based on the result of multicolinearity test presented in Table 3, it is apparent that there is no independent variables having tolerance $\leq 0.10$ and VIF $\geq 10$, and thus $\mathrm{H}_{0}$ stating that there is no multicolinearity is accepted.

\section{Autocorelation test}

Test for existence of autocorelation is conducted using Durbin-Watson test (DW test).

Table 4. Autocorelation Test

\begin{tabular}{cc}
\hline Model & Durbin-Watson \\
\hline 1 & 1.893 \\
2 & 1.970 \\
\hline
\end{tabular}

Referring to the Durbin-Watson table, it is found that $\mathrm{d}_{\mathrm{L}}=1.407$ and $\mathrm{d}_{\mathrm{U}}=1.723$, and thus $4-\mathrm{d}_{\mathrm{L}}=2.593$ and $4-\mathrm{d}_{\mathrm{U}}=2.277$. Based on the result presented in Table 4 , DW that is 1.893 (dependent variable $\mathrm{PBV}_{t 0}$ ) and 1.970 (dependent variable $\mathrm{PBV}_{\mathrm{t}+1}$ ) fit the criteria of $\mathrm{d}_{\mathrm{U}}$ $<\mathrm{D}_{\mathrm{W}}<\left(4-\mathrm{d}_{\mathrm{U}}\right)$, therefore there is no positive or negative autocorelation.

\section{Heteroscedasticity test}

The hypothesis for testing heteroscedasticity using Glejser test is $\mathrm{H}_{0}=$ there is no heteroscedasticity; $\mathrm{H}_{\mathrm{a}}=$ there is heteroscedasticity.

Table 5. Heteroscedasticity Test for Model (1)

\begin{tabular}{ll}
\hline & Sig. \\
\hline ROE & 0.473 \\
DAR & 0.550 \\
CR & 0.884 \\
CGPI & 0.635 \\
\hline
\end{tabular}


Based on the result of heteroscedasticity test in Table 5, the value of significance probability of ROE (0.473), DAR (0.550), CR (0.884), CGPI (0.635) $>\forall(0.05)$, and thus $\mathrm{H}_{0}$ stating there is no heteroscedasticity is accepted.

Table 6. Heteroscedasticity Test for Model (2)

\begin{tabular}{lc}
\hline & Sig. \\
\hline ROE & 0.882 \\
DAR & 0.041 \\
CR & 0.424 \\
CGPI & 0.543 \\
\hline
\end{tabular}

Based on the result of heteroscedasticity in Table 6, significance probability of ROE (0.882), CR (0.424), CGPI (0.543) > $\forall(0.05)$; significance probability of DAR $(0.041)<\forall$ (0.05); then $\mathrm{H}_{0}$ stating there is no heteroscedasticity is rejected or there is heteroscedasticity.

\section{Hypothesis test}

The test of $\mathrm{H}_{1}, \mathrm{H}_{2}, \mathrm{H}_{3}$, and $\mathrm{H}_{4}$ for the period $\mathrm{t}_{0}$ applies the regression Model (1).

Table 7. The Result of Test on The Impact of Financial Performance, Financial Risk, Liquidity, and CG on Corporate Value in the Period of $t_{0}$

\begin{tabular}{|c|c|c|c|}
\hline \multicolumn{4}{|c|}{$\begin{array}{c}\text { Model (1): } \\
\mathrm{PBV}_{\mathrm{t} 0}=\exists_{0}+\exists_{1} \mathrm{ROE}+\exists_{2} \mathrm{DAR}+\exists_{3} \mathrm{CR}+\exists_{4} \mathrm{CGPI}+e\end{array}$} \\
\hline Variable & $\begin{array}{c}\text { Standardized } \\
\text { Coefficients Beta }\end{array}$ & $\mathrm{t}$ & Sig. \\
\hline $\mathrm{ROE}$ & 0.601 & 4.691 & $0.000 *$ \\
\hline DAR & 0.191 & 1.037 & 0.305 \\
\hline $\mathrm{CR}$ & 0.111 & 0.646 & 0.521 \\
\hline CGPI & -0.021 & -0.159 & 0.874 \\
\hline \multicolumn{2}{|c|}{$\mathrm{F}$} & \multicolumn{2}{|c|}{5.599} \\
\hline \multicolumn{2}{|c|}{ Adjusted R Square } & \multicolumn{2}{|c|}{0.258} \\
\hline \multicolumn{2}{|c|}{ Sig. } & \multicolumn{2}{|c|}{0.001} \\
\hline
\end{tabular}

Notes:

$* \quad=1 \%$ level of significance

$* *=5 \%$ level of significance

$* * *=10 \%$ level of significance

Table 7 shows that the coefficient of ROE is positive $\left(\exists_{1}=0.601>0\right)$ and statistically significant on one percent level of significance $(t=4.691>t$ table $=2.403$ and sig. $0,000<$ 
0.01). Therefore, $H_{1}$ for the period $t_{0}$ is accepted. The coefficient of DAR is positive $\left(\exists_{2}=0.191\right.$ $>0)$ and insignificant statistically $(\mathrm{t}=1.037>-\mathrm{t}$ table $=-1.299$ and sig. $0.305>0.10)$. Thus, $\mathrm{H}_{2}$ in the period $\mathrm{t}_{0}$ is rejected. The coefficient of $\mathrm{CR}$ is positive $\left(\exists_{3}=0.111>0\right)$ and insignificant statistically $(\mathrm{t}=0.646<\mathrm{t}$ table $=1.299$ and sig. $0.521>0.10)$. Thus, $\mathrm{H}_{3}$ in $\mathrm{t}_{0}$ is rejected. The coefficient of CGPI is negative $\left(\exists_{4}=-0.021<0\right)$ and insignificant statistically $(\mathrm{t}=-0.159<\mathrm{t}$ table $=1.299$ and sig. $0.874>0.10$ ). Therefore, $\mathrm{H}_{4}$ in $\mathrm{t}_{0}$ is rejected.

The test on $\mathrm{H}_{1}, \mathrm{H}_{2}, \mathrm{H}_{3}$, and $\mathrm{H}_{4}$ in the period $\mathrm{t}_{+1}$ is conducted using regression Model (2).

Table 8. The Result of Test on the Impact of Financial Performance, Financial Risk, Liquidity, and CG on Corporate Value in the Period $t_{+1}$

\begin{tabular}{|c|c|c|c|}
\hline \multicolumn{4}{|c|}{ Model (2): } \\
\hline Variable & $\begin{array}{c}\text { Standardized } \\
\text { Coefficients } \\
\text { Beta }\end{array}$ & $\mathrm{t}$ & Sig. \\
\hline ROE & 0.568 & 4.464 & $0.000 *$ \\
\hline DAR & 0.279 & 1.528 & 0.133 \\
\hline $\mathrm{CR}$ & 0.043 & 0.254 & 0.800 \\
\hline CGPI & 0.150 & 1.133 & 0.263 \\
\hline \multicolumn{2}{|c|}{ Nilai F } & \multicolumn{2}{|c|}{5.829} \\
\hline \multicolumn{2}{|c|}{ Adjusted R Square } & \multicolumn{2}{|c|}{0.267} \\
\hline \multicolumn{2}{|c|}{ Sig. } & \multicolumn{2}{|c|}{0.001} \\
\hline
\end{tabular}

Notes:

$* \quad=1 \%$ level of significance

$* *=5 \%$ level of significance

$* * *=10 \%$ level of significance

Table 8 shows that ROE coefficient is positive $\left(\forall_{1}=0.568>0\right)$ and significant statistically on the level of one percent $(\mathrm{t}=4.464>\mathrm{t}$ table $=2.403$ and sig. $0.000<0.01)$. Therefore, $H_{1}$ in the period $t_{+1}$ is accepted. DAR coefficient is positive $\left(\forall_{2}=0.279>0\right)$ and insignificant statistically $(\mathrm{t}=1.528>-\mathrm{t}$ table $=\quad-1.299$ and sig. $0.133>0.10)$. Thus, $\mathrm{H}_{2}$ in the period $t_{+1}$ is rejected. CR coefficient is positive $\left(\forall_{3}=0.043>0\right)$ and insignificant statistically $(\mathrm{t}=0.254<\mathrm{t}$ table $=1.299$ and $0.800>0.10)$. Therefore, $\mathrm{H}_{3}$ in the period $\mathrm{t}_{+1}$ is 
rejected. CGPI coefficient is also positive $(\forall 4=0.150>0)$ and insignificant statistically $(\mathrm{t}=$ $1.133<\mathrm{t}$ table $=1.299$ and $0.263>0.10$ ). Thus, $\mathrm{H}_{4}$ in the period $\mathrm{t}_{+1}$ is rejected.

This research compares the impact of financial performance, financial risk, and liquidity on corporate value in the period $t_{0}$ and $t_{+1}$. Table 9 presents the results of the comparison.

Table 9. Comparison of Impact of Financial Performance, Financial Risk, and Liquidity on Corporate Value in the Period $t_{0}$ and $t_{+1}$

\begin{tabular}{|c|c|c|c|c|c|c|c|c|}
\hline \multicolumn{4}{|c|}{$\begin{array}{cc}\text { Model (2): } \\
\mathrm{PBV}_{\mathrm{t}+1}= & \forall_{0}+\forall_{1} \mathrm{ROE}+\forall_{2} \mathrm{DAR}+ \\
& \forall_{3} \mathrm{CR}+\forall_{4} \mathrm{CGPI}+e\end{array}$} & \multicolumn{4}{|c|}{$\begin{array}{c}\text { Model (1): } \\
\mathrm{PBV}_{\mathrm{t} 0}=\exists_{0}+\exists_{1} \mathrm{ROE}+\exists_{2} \mathrm{DAR}+ \\
\exists_{3} \mathrm{CR}+\exists_{4} \mathrm{CGPI}+e\end{array}$} & \multirow{2}{*}{$\begin{array}{c}\Delta \\
\text { Std. } \\
\text { Coeff. } \\
\text { Beta }\end{array}$} \\
\hline Var. & $\begin{array}{l}\text { Std. } \\
\text { Coeff. } \\
\text { Beta }\end{array}$ & $\mathrm{t}$ & Sig. & Var. & $\begin{array}{l}\text { Std. } \\
\text { Coeff. } \\
\text { Beta }\end{array}$ & $\mathrm{t}$ & Sig. & \\
\hline ROE & 0.568 & 4.464 & $000^{*}$ & ROE & 0.601 & 4.691 & $0.000^{*}$ & -0.033 \\
\hline DAR & 0.279 & 1.528 & 0.133 & DAR & 0.191 & 1.037 & 0.305 & 0.088 \\
\hline $\mathrm{CR}$ & 0.043 & 0.254 & 0.800 & $\mathrm{CR}$ & 0.111 & 0.646 & 0.521 & -0.068 \\
\hline CGPI & 0.150 & 1.133 & 0.263 & CGPI & -0.021 & -0.159 & 0.874 & 0.171 \\
\hline \multicolumn{3}{|c|}{ Nilai F } & 5.829 & \multicolumn{3}{|c|}{ Nilai F } & 5.599 & \multirow{3}{*}{$\begin{array}{l}\bar{R}^{2}{ }_{2}- \\
\bar{R}^{2}{ }_{1}= \\
0.009\end{array}$} \\
\hline \multirow{2}{*}{\multicolumn{3}{|c|}{ Adjusted R Square $\left(\bar{R}_{2}^{2}\right)$}} & 0.267 & \multicolumn{3}{|c|}{ Adjusted R Square $\left(\bar{R}^{2}{ }_{1}\right)$} & 0.258 & \\
\hline & & & 0.001 & \multicolumn{3}{|c|}{ Sig. } & 0.001 & \\
\hline
\end{tabular}

Notes:

$* \quad=1 \%$ level of significance

$* *=5 \%$ level of significance

$* * *=10 \%$ level of significance

To test whether there is difference between the impact of financial performance, financial risk, liquidity, and CG on corporate value in the period $t_{0}$ and $t_{+1}$ is conducted by referring to the difference $(\Delta)$ value of coefficient of ROE, DAR, CR, CGPI in the Model (2) and Model (1). Table 9 shows that coefficient of ROE decreases $\left(\forall_{1}-\exists_{1}=-0.033\right)$, coefficient of DAR increases $\left(\forall_{2}-\exists_{2}=0.088\right)$, coefficient of CR decreases $\left(\forall_{3}-\exists_{3}=-0.068\right)$, and coefficient of CGPI increases $\left(\forall_{4}-\exists_{4}=0.171\right)$. The value of adjusted $\mathrm{R}$ square increases from $\overline{\mathrm{R}}^{2}{ }_{1}=0.258$ or 25.8 percent to $\overline{\mathrm{R}}^{2}{ }_{2}=0.267$ or 26.7 percent $\left(\overline{\mathrm{R}}^{2}{ }_{2}-\overline{\mathrm{R}}^{2}{ }_{1}=0.009\right)$. 
Significance of the increase of $\overline{\mathrm{R}}^{2}$ is analyzed by comparing $\mathrm{Z}$ value (F-test) and Ftable. The calculation results in $\mathrm{Z}$ value $(\mathrm{F}$-test $)=0.077<\mathrm{F}$-table $=2.56$. This means that difference of the impact of financial performance, financial risk, liquidity, and CG on corporate value in $t_{0}$ and $t_{+1}$ is insignificant statistically.

\section{Discussion}

\section{The impact of financial performance on corporate value}

The test on $\mathrm{H}_{1}$ in the period $\mathrm{t}_{0}$ as presented in Table 7 shows that ROE has positive impact on $\mathrm{PBV}_{\mathrm{t} 0}$ (one percent level of significance). The test on $\mathrm{H}_{1}$ in the period $\mathrm{t}_{+1}$ as presented in Table 8 shows that ROE influences $\mathrm{PBV}_{\mathrm{t}+1}$ positively (one percent level of significance). Therefore, it can be concluded that $\mathrm{H}_{1}$ is accepted.

This result is similar to the research of Safitri, Handayani, \& Nuzula (2014) that tested the impact of profitability (NPM, ROA, ROE, EPS) on corporate value (PBV and stock price). The result showed that profitability had positive impact on corporate value (one percent level of significance). The result of this research is also in line with the research of Marlina (2013) and Marangu \& Jagongo (2014) that concluded ROE influenced PBV positively (one percent level of significance).

Higher ROE indicates better ability of the management in generating profit to leverage the owner's equity. ROE influences PBV positively in both the period $t_{0}$ and $t_{+1}$ (one percent level of significance). Good financial performance of a company is the consideration of investorsfor making decisions to buy company's stocks. Higher demand on company's stocks increases price of the stocks. This in turn brings impact on the increase of corporate value.

Value of ROE will increase when the management is able to manage the equity of the company well, which in turn produces optimal net profit. Equity is invested on assets which 
will be used in company's operations for generating sales. High level of sales or low operational costs will result in higher net profit. Some amount of the net profit can be used to pay investors in the form of dividend and the rest known as retained earning can be reinvested in the company to support the company growth.

\section{The impact of financial risk on corporate value}

The test on $\mathrm{H}_{2}$ in the period $\mathrm{t}_{0}$ as presented in Table 7 shows that DAR has positive but insignificant impact on $\mathrm{PBV}_{\mathrm{t} 0}$. The test on $\mathrm{H}_{2}$ in the period $\mathrm{t}_{+1}$ as presented in Table 8 shows that DAR influences $\mathrm{PBVt}_{+1}$ positively but insignificantly. It thus can be concluded that $\mathrm{H}_{2}$ is rejected.

DAR as the proxy of financial risk shows ratio between total debts to total assets. The result in the period $t_{0}$ and $t_{+1}$ stating that DAR influences PBV positively but statistically insignificant indicates that DAR does not reflect financial risks of a company. The investors do not consider higher DAR as negative news but rather positive one.

According to Helfert (1996), financial performance can be evaluated from three point of views: owner, management, and creditors. From the creditors' perspective, financial performance of a company relates to the ability of the company to pay back the debts. If the historical data show that the company is always able to pay its debts, the creditors' trust to the financial performance of the company will increase accordingly. Indirectly, the amount of debts given by the creditors also reflects trust level of the creditors (external stakeholders of the company) on the capability of the internal entity in managing the company. This creates positive perception of the investors and thus DAR has positive impact on the corporate value.

In this research, average proportion of debts in the total assets is 49.84 percent. This average of DAR is categorized as medium. As far as the company is able to do their liabilities in paying the debts, the DAR is considerably good for the company growth and progress. The 
insignificant impact of DAR on PBV shows that investors do not view DAR as the important factor in evaluating a company conditions. The proportion of debts in the company's assets does not influence significantly on the increase or decrease of the corporate value. For investors, capability of the management in managing equity for producing profit is the more important factor.

\section{The impact of liquidity on corporate value}

The test on $\mathrm{H}_{3}$ in the period $\mathrm{t}_{0}$ as presented in Table 7 shows that $\mathrm{CR}$ influences $\mathrm{PBV}_{\mathrm{t} 0}$ positively but not statistically significant. The test on $\mathrm{H}_{3}$ in the period $\mathrm{t}_{+1}$ as presented in Table 8 shows that $\mathrm{CR}$ influences $\mathrm{PBVt}_{+1}$ positively but not statistically significant. Therefore, it can be concluded that $\mathrm{H}_{3}$ is rejected. This result is in line with the results of Nurhayati (2013) and Stiyarini \& Santoso (2016) mentioning that CR influences PBV positively but not statistically significant.

$\mathrm{CR}$ as a proxy to company liquidity shows ratio current assets to current liabilities. The higher CR indicates higher capability of the company to pay its current liabilities using current assets. The mean value of CR in this research is 1.59 . The result of the research for the period $t_{0}$ and $t_{+1}$ designates that CR influences PBV positively but statistically insignificant. The level of the company to pay their short-term debts using the current assets does not influence significantly to the increase or decrease of the corporate value. The cause of this is liquidity of the company measured using CR relates to the company short-term conditions. Meanwhile investors pay more attention to the capability of the company in producing profit that can support company growth and sustainability.

\section{The impact of corporate governance on corporate value}

The test on $\mathrm{H}_{4}$ in the period $\mathrm{t}_{0}$ as presented in Table 7 shows that CGPI has negative impact on $\mathrm{PBV}_{\mathrm{t} 0}$ but the impact is statistically insignificant. The test on $\mathrm{H}_{4}$ in the period $\mathrm{t}_{+1}$ as 
presented in Table 8 shows that CGPI has positive impact on $\mathrm{PBV}_{\mathrm{t}+1}$ but it is statistically insignificant. Thus, it can be concluded that $\mathrm{H}_{4}$ is rejected.

The test to $\mathrm{H}_{4}$ in the period $\mathrm{t}_{+1}$ is in line with the results of Pratiwi \& Rahayu (2015) stating that CGPI influences PBV positively but insignificantly. CGPI as a proxy to corporate governance indicates the level of implementation of corporate governance. This research comes up with mean of CGPI is 81.52. This means that the sample companies are on average in the category of trusted company.

Generally, investments do not always result in fund or money. In green business context, sacrificing on economic resources for green business will be treated as investment that will result in economic and non economic benefits for the company in the future (Lako, 2014). Even though in the short-term internalization of green business principles in decisions and business actions reduces profit, they however will bring benefits for the company in the longterm. Such condition applies to the company's efforts in implementing CG. Recently, investment in CG has not yet considered as thing that brings direct benefits for the shareholders. Its positive impact can only be seen in the next period (one year) even though it has not been the important factor for investors in making the decision to buy company's stocks.

Statistically, the level of company capability in implementing CG principles does not influence significantly the level of corporate value. The reasons are: 1) Information about CGPI score does not reach the investors since it is not available in the financial reports of the company. In other words, investors do not know CGPI score of the company at the time they make investment decisions; 2) investors do not consider CGPI as an important factor in evaluating conditions of a company. 


\section{CONCLUSIONS AND RECOMMENDATIONS}

\section{Conclusions}

Based on the results and discussion, it can be concluded that financial performance (ROE) has a positive impact on the corporate value. Financial risk (DAR) has a positive impact on the corporate value but statistically insignificant. Liquidity (CR) has a positive impact on the corporate value, but statistically insignificant. CG (CGPI) provides negative influence to corporate value in the period of $t_{0}$ but statistically insignificant, while it influences positively in the period of $t_{+1}$ to corporate value but insignificant statistically.

\section{Recommendations}

The main factor a company needs to consider for leveraging corporate value is financial performance, especially return on equity (ROE). Better financial performance of a company (higher ROE) will give positive signal for investors in making decisions to buy company's shares that in turn will increase its corporate value. Therefore, the company needs to manage its equity well in order to generate optimal net profit.

Research in the future can use variables other than CGPI as a proxy of corporate governance to add the number of population members and obtain more variety of companies. The researchers can also add other variables that have influence to corporate value such as dividend policy and corporate social responsibility. 


\section{REFERENCES}

Brealey, R. A., Myers, S. C., \& Marcus, A. J. (2012a). Dasar-dasar Manajemen Keuangan Perusahaan Jilid 1 (Edisi 5). Jakarta: Erlangga.

Brealey, R. A., Myers, S. C., \& Marcus, A. J. (2012b). Dasar-dasar Manajemen Keuangan Perusahaan Jilid 2 (Edisi 5). Jakarta: Erlangga.

Brigham, E. F., \& Houston, J. F. (2014a). Dasar-dasar Manajemen Keuangan Buku 1 (Edisi 11). Jakarta: Salemba Empat.

Brigham, E. F., \& Houston, J. F. (2014b). Dasar-dasar Manajemen Keuangan Buku 2 (Edisi 11). Jakarta: Salemba Empat.

Damodaran, A. (2012). Investment Valuation: Tools and Techniques for Determining the Value of Any Asset (Third Edit). New Jersey: John Wiley \& Sons.

Dwipayana, M. A. T., \& Suaryana, I. G. N. A. (2016). Pengaruh Debt to Assets Ratio, Devidend Payout Ratio, dan Return on Assets Terhadap Nilai Perusahaan. E-Jurnal Akuntansi Universitas Udayana, 17(3), 2008-2035. Retrieved from https://ojs.unud.ac.id/index.php/Akuntansi/article/view/22313

Fahmi, I. (2015). Manajemen Investasi: Teori dan Soal Jawab (Edisi 2). Jakarta: Salemba Empat.

Ghozali, I. (2013). Aplikasi Analisis Multivariate dengan Program IBM SPSS 21. Semarang: Badan Penerbit Universitas Diponegoro.

Hariyanto, M. S., \& Lestari, P. V. (2015). Pengaruh Struktur Kepemilikan, IOS, dan ROE Terhadap Nilai Perusahaan Pada Perusahaan Food and Beverage. E-Jurnal Manajemen Unud, 4(4), 1599-1626. Retrieved from https://ojs.unud.ac.id/index.php/Manajemen/article/view/16969/13152

Helfert, E. A. (1996). Teknik Analisis Keuangan: Petunjuk Praktis untuk Mengelola dan Mengukur Kinerja Perusahaan. Jakarta: Erlangga.

Inastri, M. A., \& Mimba, N. P. S. H. (2017). Pengaruh Penerapan Good Corporate Governance dan Pengungkapan Corporate Social Responsibility pada Nilai Perusahaan. E-Jurnal Akuntansi Universitas Udayana, 21(2), 1400-1429. Retrieved from https://ojs.unud.ac.id/index.php/Akuntansi/article/view/34037

Komite Nasional Kebijakan Governance. (2006). Pedoman Umum Good Corporate Governance Indonesia. Pedoman Umum Good Corporate Governance Indonesia, 30. Retrieved from http://www.ecgi.org/codes/documents/indonesia_cg_2006_id.pdf

Lako, A. (2007). Relevansi Nilai Informasi Laporan Keuangan untuk Pasar Saham: Pengujian Berbasis Teori Valuasi dan Pasar Efisien. Disertasi. Universitas Gadjah Mada. Yogyakarta. 
Lako, A. (2014). Green Economy: Menghijaukan Ekonomi, Bisnis, dan Akuntansi. Jakarta: Erlangga.

Marangu, K., \& Jagongo, A. (2014). Price to Book Value Ratio and Financial Statement Variables (An Empirical Study of Companies Quoted At Nairobi Securities Exchange, Kenya), 3(6), 50-56. Retrieved from http://business.ku.ac.ke/images/stories/docs/price_book_ratio.pdf

Marlina, T. (2013). Pengaruh Earning Per Share, Return On Equity, Debt To Equity Ratio dan Size Terhadap Price To Book Value. Jurnal Ilmiah Akuntansi Kesatuan, 1(1), 59-72. Retrieved from

http://digilib.mercubuana.ac.id/manager/t!@file_artikel_abstrak/Isi_Artikel_715653482132.p df

Nurhayati, M. (2013). Profitabilitas, Likuiditas dan Ukuran Perusahaan Pengaruhnya Terhadap Kebijkan Dividen dan Nilai Perusahaan Sektor Non Jasa. Jurnal Keuangan Dan Bisnis, 5(2), 144-153.

Retrieved from https://www.researchgate.net/publication/326551702_PROFITABILITAS_LIKUIDITAS_D AN_UKURAN_PER

OJK. (2014). Roadmap Tata Kelola Perusahaan Indonesia, 84. Retrieved from https://www.ojk.go.id/id/data-dan-

statistik/ojk/Documents/ROADMAPTATAKELOLAPERUSAHAANINDONESIA_1391520 776.PDF

Pratiwi, N., \& Rahayu, S. (2015). Pengaruh Profitabilitas, Leverage, Good Corporate Governance, dan Ukuran Perusahaan Terhadap Nilai Perusahaan (Studi Kasus pada Perusahaan yang Terdaftar pada Bursa Efek Indonesia yang Memiliki Skor CGPI selama Periode 2010 2013). Jurnal E-Proceeding of Management, 2(3), 3146-3152. Retrieved from https://libraryeproceeding.telkomuniversity.ac.id/index.php/management/article/view/1900/1 803

Purwanto, P., \& Agustin, J. (2017). Financial Performance towards Value of Firms in Basic and Chemicals Industry. European Research Studies Journal, XX(2A), 443-460. Retrieved from http://www.ersj.eu/repec/ers/papers/17_2_A_p27.pdf

Sadeli, F. (2011). Lika liku Strategi Keuangan Perusahaan: Panduan Praktis Meningkatkan Nilai Perusahaan. Jakarta: Salemba Empat.

Safitri, O. N., Handayani, S. R., \& Nuzula, N. F. (2014). The Influence of Capital Structure and Profitability on Firm Value (A Study in Retail Companies Listed in Indonesia Stock Exchange 2010-2013 Period ). Jurnal Administrasi Bisnis (JAB), 13(2), 1-19. Retrieved from http://administrasibisnis.studentjournal.ub.ac.id/index.php/jab/article/view/557

Stiyarini, \& Santoso, B. H. (2016). Pengaruh Kinerja Keuangan Terhadap Nilai Perusahaan Pada Perusahaan Jasa Telekomunikasi. Jurnal Ilmu Dan Riset Manajemen, 5(2), 1-21. Retrieved from https://ejournal.stiesia.ac.id/jirm/article/view/1466/1424 
Sulastri, E. M., \& Nurdiansyah, D. H. (2017). Pengaruh Good Corporate Governance terhadap Kinerja dan Nilai Perusahaan (Studi pada Perusahaan yang Terindeks oleh CGPI). Jurnal Manajerial, 2(2), 35-45. from http://ejournal.upi.edu/index.php/manajerial/article/view/10433/6443

Sutedi, A. (2011). Good corporate Governance. Jakarta: Sinar Grafika.

SWA. (2016). Indonesia Most Trusted Companies 2016. SWA 27, 20 Desember 2016 - 4 Januari 2017. 